УДК 343.811

DOI https://doi.org/10.32849/2663-5313/2021.5.38

\title{
Станіслав Мозоль,
}

докт. юрид. наук, стариий науковий співробітник,

доцент кафедри кримінології та кримінально-виконавчого права

Начіональної академії внутрішніх справ

\section{Геннадій Полішук,}

канд. юрид. наук, доиент,

професор кафедри кримінології та кримінально-виконавчого права

Національної академії внутрішніх справ

\author{
Анастасія Тернавська, \\ канд. юрид. наук, \\ головний спечіаліст відділу забезпечення діяльності Дисииллінарних палат \\ Управління з питань відповідальності суддів і прокурорів \\ Секретаріату Вищої ради правосуддя
}

\section{ОРГАНІЗАЦІЙНО-ПРАВОВІ ЗАХОДИ ЗАПОБІГАННЯ СУЇЦИДУ СЕРЕД ЗАСУДЖЕНИХ У ВИПРАВНИХ КОЛОНІЯХ УКРАЇНИ}

Актуальність статті полягає в тому, що важливим показником рівня охорони життя та здоров'я в установах виконання покарань є число випадків неприродної смерті, зокрема суїиду. Вивчення зазначеного феномена є важливим завданням, належне вирішення якого здатне суттєво покращити процес виконання та відбування кримінальних покарань $і$ позитивно вплинути на можливості реінтеграиї̈ звільнених осіб у суспільство, адже існування таких форм поведінки свідчить, з одного боку, про нездатність держави забезпечувати безпеку особи, а з іншого - про неадекватний вибір покарання для особи, яка є потениійним носієм суїцдальних схильностей. Темпи поширення иього негативного явища зростають і перетворюються на серйозну сочіальну проблему, а різке зростання випадків учинення суӥицду негативно впливає на стабільне функиіонування установ виконання покарань та унеможливлює гарантування безпеки спеиконтингенту, що є одним із основних обов'язків персоналу установ виконання покарань. Метою статті є характеристика основних напрямів запобігання суїииду серед засуджених у виправних колоніях України, зокрема його організачійно-правового складника, і формулювання пропозииій щодо його вдосконалення. У статті виокремлено, надано опис і пояснення організаційно-правових заходів запобігання суйииду серед засуджених у виправних колоніях Украйни. Розроблено пропозииї шодо антисуїицдальної спеиифікаиії наиіонального превентивного механізму. Аргументовано необхідність вилучення з тексту закону положення ч. 4 cm. 19-1 Закону України «Про Уповноваженого Верхової Ради Украйни з прав людини» щодо роботи моніторів виключно на підставі окремого доручення омбудсмена. Доведена необхідність створення в структурі відділень соиіально-психологічної служби виправних колоній окремих секторів запобігання суйцидам. Спроектовано зміни й відповідні доповнення до Положення про відділення соиіальнопсихологічної служби. Запропоновано внести зміни до Переліку веб-сайтів, до яких дозволяється доступ засудженим, а також розроблено проект програми диферениійованого виховного впливу на засуджених «Подолання саморуйнівних станів», запровадження якої має усунути організаційно-правову прогалину в роботі із суїицдентами серед засуджених у виправних колоніях.

Ключові слова: суїид, виправні колонії, засуджені, запобіжна діяльність, організаційно-правові заходи.

Постановка проблеми. Визначення дієвих способів і шляхів запобігання девіантній поведінці в сучасному українському суспільстві, зокрема такій їі небезпечній формі, як суїцид, є однією з актуальних соціальних і правових проблем. Так, положеннями Національної стратегії у сфері прав людини, затвердженої Указом Президента України від 24 березня 2021 року № 119/2021, установлено, що життя кожної людини в Україні має перебувати під ефективною охороною та правовим захистом держави [1]. Отже, забезпечення права на життя, яке визнається найвищою соціальною цінністю, його захист 
є обов'язком держави. Суӥцид як форма девіантної поведінки людини, спрямована на навмисне позбавлення себе життя, є свідомим нехтуванням цими цінностями. Тобто це деструктивне явище можна розцінювати як злочин людини проти себе самої та віднести його до найбільш складних і болючих психолого-правових проблем сьогодення.

Важливим показником рівня охорони життя та здоров'я в установах виконання покарань $є$ число випадків неприродної смерті, зокрема суїциду. Вивчення зазначеного феномена є важливим завданням, належне вирішення якого здатне суттєво покращити процес виконання та відбування кримінальних покарань і позитивно вплинути на можливості реінтеграції звільнених осіб у суспільство, адже існування таких форм поведінки свідчить, з одного боку, про нездатність держави забезпечувати безпеку особи, а з іншого - про неадекватний вибір покарання для особи, яка $є$ потенційним носієм суїцидальних схильностей.

Варто зауважити, що темпи поширення цього негативного явища зростають і перетворюються на серйозну соціальну проблему, а різке зростання випадків учинення суїциду негативно впливає на стабільне функціонування установ виконання покарань та унеможливлює гарантування безпеки спецконтингенту, що є одним із основних обов'язків персоналу установ виконання покарань.

Аналіз статистичних даних Державної кримінально-виконавчої служби України засвідчує наявність небезпечних тенденцій у стані суїциду серед засуджених, що відбувають покарання у вигляді позбавлення волі. Так, якщо розрахований середній щорічній рівень облікованих випадків суїциду залишається протягом останніх років відносно стабільним (50 випадків), то відносні показники суїциду мають стійку тенденцію до зростання. Зокрема, співвідношення кількості випадків суїциду серед засуджених до загальної їх кількості в установах виконання покарань збільшилося у п’ять разів: $з$ 0,21 випадків суїциду у 2003 році на 1000 засуджених до 1,04 у 2020 році. Середні значення зазначеного показника більше ніж удвічі перевищують рівень суїциду серед населення в Україні (57,5 випадків серед засуджених проти 21,2 випадки серед населення) та є одним із найвищих серед пенітенціарних служб країн ЄС [2, с. 56].

Отже, зважаючи на розповсюдженість проявів агресивної поведінки засуджених у виправних колоніях, значну соціальну небезпеку суїциду, його негативний вплив на процес виправлення та збереження психічного здоров'я особистості, проблема визна- чення детермінуючих чинників та ефективних заходів запобігання суїциду серед засуджених у виправних колоніях зберігає свою теоретичну й практичну актуальність для кримінально-виконавчої системи України.

У спеціальній літературі, вітчизняній і зарубіжній, питанню запобігання суїциду в установах виконання покарань приділялася значна увага. Так, Ю.В. Александров, А.Г. Амбрумова, Ю.М. Антонян, В.В. Білецький, О.В. Беца, І.Г. Богатирьов, С.В. Бородін, Е.К. Волконська, М.Г. Дебольський, О.М. Джужа, О.Г. Ермолаєва, З.В. Журавська, В.О. Кірієнко, О.Г. Колб, І.А. Матвєєва, Л.М. Мелентьєв, А.С. Михлин, О.М. Моховіков, В.В. Новіков, Г.С. Поліщук, Г.О. Радов, В.В. Розанов, І.В. Сингаївська, В.М. Синьов, Р.В. Стіліха, О.В. Старков, В.В. Суліцький, В.А. Тихоненко, А.П. Тищенко, Г.Ф. Хохряков, В.О. Шаповалов, Р.А. Шахманов, Л.М. Шестопалова, О.О. Шкута, І.В. Шмаров та інші науковці висвітлювали окремі питання проблеми суїциду й пов'язаних 3 ним явищ в установах виконання покарань. Наукові положення, сформульовані зазначеними дослідниками, мають вагоме теоретичне та практичне значення, але зміна та стрімкий розвиток суспільних відносин, значна зміна чинного законодавства зумовлюють потребу повертатися до цього питання, досліджуючи його в динаміці.

Метою статті є характеристика основних напрямів запобігання суїциду серед засуджених у виправних колоніях України, зокрема його організаційно-правового складника, і формулювання пропозицій щодо його вдосконалення.

Виклад основного матеріалу. Прийнято вважати, що спеціально-кримінологічні заходи запобігання злочинності й фоновим для неї явищам реалізуються спеціальними суб'єктами кримінологічної діяльності, які формують властивими їх правовому статусу методами, формами антикриміногенного впливу на групові девіантогенні фактори. Виходячи з усталеної логіки розуміння сутності спеціально-кримінологічного запобігання й у перекладанні іï на площину проблематики цього дослідження, випливає, що об'єктом запобіжного впливу мають бути особи, які відбувають покарання у виправних колоніях, їхні особистості. Визнаючи слушність і високий ступінь обгрунтованості цього підходу, усе ж вважаємо за доцільне розрізняти об'єкти запобіжного впливу та об'єкти запобігання злочинності й фоновим для неї явищам.

У цьому контексті варто погодитися з В.В. Голіною, який, проводячи розмежу- 
вання між указаними категоріями наукового пізнання та кримінологічної практики, обгрунтовано стверджує, що об'єкт запобігання злочинності - це явища та процеси реальної дійсності матеріального, правового й духовного характеру, існування й різнобічний вплив яких призводить до відтворення на суспільному рівні злочинності як соціального явища, масової деструктивності, кримінальної мотивації, наміру, прийняття рішення на вчинення злочинів і їх реалізації. Об'єкт має певну генеруючу силу впливу на суспільні відносини [3, с. 65]. Водночас поняття «запобіжний вплив» відбиває властивість діяння, сила якого здатна стабілізувати, регулювати або вносити запрограмовані зміни в стан об'єкта. Запобіжний вплив є тиском, цілеспрямованим зусиллям суб'єкта на максимально конкретизований, реально уразливий для його дій об'єкт $[3$, с. $65 ; 4$, c. 157]

Тому, якщо об'єктом спеціально-кримінологічного запобіжного впливу дійсно маємо визнавати засуджених до позбавлення волі, які відбувають покарання у виправних колоніях України, то об'єктом запобігання суїцидам серед таких засуджених варто визнавати відповідні групові фактори суїциду. Але й цього недостатньо для успішного виконання відповідних превентивних задач. Необхідно враховувати, що соціальна група є недостатнім критерієм для належної специфікації кримінально-превентивної діяльності. У межах будь-якої, навіть вельми однорідної, соціальної групи відтворюється, як правило, низка неоднорідних чинників соціогенези. Будь-яка група може бути поділена на більш дрібні підгрупи, утворення залежно від чинників диференціації меншого рівня абстрагування, вищого рівня прагматизації. Отже, групові фактори суїцидів серед засуджених у межах організації та здійснення спеціально-кримінологічного запобігання їх поширенню необхідно розробляти й реалізовувати, додатково спираючись на видову градації відповідних суїцидогенних факторів. А вони різні, що доведено нами.

Отже, спеціально-кримінологічні заходи запобігання суӥцидам серед засуджених у виправних колоніях України - це здійснювані спеціальними суб'єктами заходи нейтралізації (послаблення впливу) групових і видових факторів суїциду, що відтворюються в соціокультурному, режимно-побутовому, адміністративно-комунікативному та особистісно-психологічному просторі життєдіяльності засуджених у виправних колоніях [5, с. 105].

Вагомим превентивним потенціалом у структурі спеціально-кримінологічних захо- дів запобігання характеризуються організаційно-правові заходи, які мають бути заточені на підвищення кримінологічної ефективності правового регулювання у сфері запобігання суїцидам серед засуджених у виправних колоніях. Зрозуміло, що проблема кримінологічної ефективності правового регулювання сама по собі є фундаментальною і навіть часткове її вирішення не може бути забезпечене в межах цього, а так само будь-якого іншого дослідження з проблем особливої частини кримінології. Одна, наявний теоретичний доробок iз цих питань дає нам змогу стверджувати, що основними напрямами вдосконалення правового регулювання у сфері запобігання суїцидам серед засуджених у виправних колоніях є правотворчість і правореалізація (правозастосування). I якщо перше $\epsilon$, так би мовити, комплексом правових заходів y «чистому вигляді», то друге є симбіозом правових та організаційно-управлінських заходів [2, с. 125]. Саме тому ми використовуємо семантичну зв'язку «організаційно-правові заходи». На нашу думку, до них доцільно зарахувати такі:

А. Антисуїцидальну специфікацію національного превентивного механізму вдосконалення правових засад його функціонування. Реалізація цього заходу вбачається, по-перше, у розширенні функціоналу національного превентивного механізму, виведенні антисуїцидальних фонових, вторинних ефектів його застосування до розряду основних, актуальних. Ідеться про:

а) артикуляцію завдань запобігання суїциду серед осіб, які утримуються в місцях несвободи (у тому числі й у виправних колоніях), що видається через публічне, наукове фахове обговорення, дослідження широти спектру кримінологічних можливостей національного превентивного механізму з відповідною нормативно-правовою фіксацією їх основних важелів;

б) системне вдосконалення механізмів функціонування національного превентивного механізму з метою підвищення його кримінологічної ефективності, у тому числі й зокрема 3 питань запобігання суїцидам серед засуджених до позбавлення волі.

Принагідно звернімо увагу, що, відповідно до ч. 4 ст. 19-1 Закону України «Про Уповноваженого Верхової Ради України з прав людини» від 23.12.1997 № 776/97-ВР, представники громадських організацій, експерти, учені та фахівці, залучені Уповноваженим на договірних засадах до виконання функцій національного превентивного механізму, відвідують на підставі окремого письмового доручення Уповноваженого місця, зазначені в п. 8 ст. 13 цього Закону, і з додержанням 
вимог ч. 3 цієї статті можуть опитувати осіб, які перебувають у таких місцях, з метою отримання інформації стосовно поводження із цими особами та щодо умов їх тримання [6].

Зазначені в законі представники громадських організацій, експерти, учені та фахівці в науці та практиці діяльності національного превентивного механізму прийнято іменувати моніторами. Останніх, на нашу думку, варто наділити більшою правовою самостійністю, що вбачається через деталізацію їхніх повноважень у Законі України «Про Уповноваженого Верхової Ради України з прав людини». Зокрема, необхідно:

а) ліквідувати положення ч. 4 ст. 19-1 указаного Закону про роботу моніторів на підставі окремого доручення омбудсмена. Немає достатніх підстав уважати, що омбудсмен може бути достатньою мірою обізнаний про множинність нюансів на місцях, у кожному окремому місці несвободи, у т.ч. виправних колоніях. Для цього й мають бути укладені договори з моніторами, аби останні мали змогу оперативно, у будь-який час доби, без додаткових бюрократичних обтяжень відвідувати колонії, спілкуватися із засудженими, працівниками. Сама лише наявність такої можливості буде суттєвим фактором стримування певної категорії персоналу установ виконання покарань від протиправного поводження із засудженими;

б) передбачити, що угоди з громадською організацією чи окремими експертами, науковцями на здійснення моніторингу місць несвободи мають строковий характер. У цих угодах окремим пунктом має бути передбачено чіткий перелік осіб, які від імені громадської організації або самостійно (на підставі акредитації) мають право відвідувати місця несвободи без попереднього повідомлення про час і мету відвідувань і без обмеження їх кількості.

Отже, пропонуємо:

- ч. 4 ст. 19-1 Закону України «Про Уповноваженого Верхової Ради України з прав людини» пропонуємо викласти в такій редакції: «Представники громадських організацій, експерти, учені та фахівці в галузі права, залучені Уповноваженим на договірних засадах до виконання функцій національного превентивного механізму (монітори), з метою, передбаченою національним превентивним механізмом, відвідують місця, зазначені в пункті 8 статті 13 цього Закону, і з додержанням вимог частини 3 цієї статті можуть опитувати осіб, які перебувають у таких місцях, з метою отримання інформації стосовно поводження із цими особами, щодо умов їх тримання, стану здоров'я, наявності передумов для вчинення самогубств»;
- ч. 7 ст. 19-1 цього Закону доповнити, виклавши в такій редакції: «У секретаріаті Уповноваженого утворюється окремий структурний підрозділ із питань недопущення катувань, інших жорстоких, нелюдських або таких, що принижують гідність, видів поводження, покарання та запобігання самогубствам. До роботи в цьому структурному підрозділі з додержанням рівного представництва чоловіків і жінок і представництва національних меншин залучаються фахівці різних спеціальностей, які мають належну професійну підготовку»;

- доповнити Закон України «Про Уповноваженого Верхової Ради України з прав людини» статтею 19-2 такого змісту:

«Стаття 19-2. Корпус моніторів національного превентивного механізму

1. Для реалізації функції національного превентивного механізму Уповноважений формує корпус моніторів як постійно функціонуючої системи спостереження за місцями несвободи. Уповноважений здійснює координацію роботи корпусу моніторів.

2. Монітором національного превентивного механізму може бути представник громадської організації, з якою Уповноваженим укладено угоду на виконання функцій національного превентивного механізму, а також окремі експерти, учені та фахівці в галузі права, акредитовані на здійснення функцій національного превентивного механізму відповідно до встановленого законом порядку та 3 якими Уповноваженим укладено угоду на виконання функцій національного превентивного механізму.

3. Корпус моніторів складається 3 професійних моніторів, що працюють на постійній оплатній основі, і волонтерів, які здійснюють функції національного превентивного механізму на безоплатній основі. Держава встановлює додаткові соціальні гарантії для волонтерів корпусу моніторів національного превентивного механізму шляхом визначення пільг і преференцій у сфері освіти, оплати житлово-комунальних послуг.

4. Гранична кількість моніторів визначається Уповноваженим один раз на п'ять років 3 урахуванням кількості місць несвободи, поширеності в них порушень прав людини, фактичних і науково обгрунтованих потреб у забезпеченні належного їх моніторингу.

5. Завданнями моніторів національного превентивного механізму є:

- виявлення та фіксація фактів незаконного утримання людей у місцях несвободи

- виявлення та фіксації фактів катувань, жорстокого, іншого нелюдського поводження з утримуваними в місцях несвободи людьми; 
- виявлення фактів самогубств (у тому числі й спроб самогубств) серед утримуваних у місцях несвободи;

- сприяння наданню всебічної правової, медичної, психіатричної, психологічної допомоги утримуваним у місцях несвободи особам, які стали жертвами катувань, жорстокого, іншого нелюдського поводження, учинили спробу самогубства або виказують наміри про вчинення суїцидального акту.

6. 3 метою виконання покладених на моніторів завдань вони можуть:

- безперешкодно в будь-який час доби без попередження відвідувати місця несвободи без обмеження кількості й тривалості візитів;

- опитувати утримуваних у них осіб, а також працівників цих місць;

- використовувати засоби відео- та фотофіксації з метою документування незаконного утримування, а також катувань, жорстокого, іншого нелюдського поводження з утримуваними в місцях несвободи;

- уносити до адміністрації місць несвободи подання про усунення виявлених недоліків, що сприяють учиненню катувань, жорстокого, іншого нелюдського поводження, а також самогубствам серед утримуваних у цих місцях.

7. Подання монітору підлягає обов'язковому розгляду адміністрацією місця несвободи протягом 10 днів з дня надходження. Про результати розгляду адміністрація місця несвободи повідомляе монітора в письмовій формі»;

в) варто криміналізувати перешкоджання законній діяльності монітора національного превентивного механізму, а саме:

- доповнити ст. ст. 343, 347 Кримінального кодексу (далі - КК) України: у назві статей, а також у диспозиціях частин 1 після слів «приватного виконавця» через кому зазначити «монітора національного превентивного механізму»;

- доповнити ст. 346 КК України: в назві статті після слів «громадського діяча» через кому зазначити «монітора національного превентивного механізму»; у диспозиції частини 1 цієї статті після слів «керівника політичної партії» через кому зазначити «монітора національного превентивного механізму».

Б. Антисуїцидальна специфікація роботи відділень соціально-психологічної служби. Варто зауважити, що нині ця робота значною мірою є безсистемною, формалізованою; не застосовуються сучасні методики діагностики та запобігання суїцидам серед засуджених; індивідуальні програми диференційованого виховного впливу «не заточені» під запити в зниженні суїцидальної активності засуджених у виправних колоніях [7, с. 203]. Сприяти виправленню цієї ситуації, на нашу думку, можуть:

а) доповнення розділу III Положення про відділення соціально-психологічної служби, затверджене наказом Міністерства юстиції від 04.11.2013 № 2300/5 [8], пунктом 30 такого змісту: «Організовувати моніторинг соціально-психологічного клімату серед засуджених, поширеності саморуйнівних форм поведінки, виявляти осіб, схильних до суїциду, забезпечувати вжиття заходів щодо запобігання їх учиненню»;

б) доповнення вказаного Положення розділом V під назвою «Сектор запобігання суїцидам серед засуджених» такого змісту: $\ll \mathrm{У}$ відділенні соціально-психологічної служби створюється сектор запобігання суїцидам. Завданнями сектору є:

- вчасна діагностика суїцидальних розладів серед засуджених;

- прогнозування розвитку суӥцидальних станів серед засуджених;

- прогнозування вчинення злочинів суїцидентами;

- вивчення причин та умов, які сприяють вчиненню суїцидів серед засуджених, вчасне вжиття заходів, спрямованих на їх усунення.

Сектор функціонує на підставі Типового положення про сектор запобігання суӥцидам віддання соціально-психологічної служби».

Певна річ, для нормальної роботи вказаних секторів необхідно буде організувати, провести навчання у формі підвищення кваліфікації, спеціалізованих тренінгів, семінарівнарад з особовим складом новостворених підрозділів з метою засвоєння ними специфічних знань про механізм суїцидальної поведінки, її фактори, способи запобігання, оволодіння навичками застосування методик відповідної превентивної діяльності.

\section{Висновки}

Проведене авторами дослідження основних напрямів запобігання суӥциду серед засуджених у виправних колоніях України дало змогу виокремити, надати опис і пояснення організаційно-правових заходів запобігання. Обгрунтовано високий превентивний потенціал зазначеної категорії заходів, розроблено пропозиції щодо антисуїцидальної специфікації національного превентивного механізму та роботи відділень соціальнопсихологічної служби виправних колоній. Зокрема, наведено аргументи на користь необхідності скасувати положення ч. 4 ст. 19-1 Закону України «Про Уповноваженого Верхової Ради України з прав людини» щодо роботи моніторів виключно на підставі окремого доручення омбудсмена, обгрунтовано 
позицію про необхідність окремого правового регулювання діяльності корпусу моніторів національного превентивного механізму, що, серед іншого, передбачає криміналізацію перешкоджання їхньої діяльності (ст. ст. 343, 346, 347 КК України). Запропоновано внести зміни до Переліку веб-сайтів, до яких дозволяється доступ засудженим, а також розроблено проект програми диференційованого виховного впливу на засуджених «Подолання саморуйнівних станів», запровадження якої має усунути організаційно-правову прогалину в роботі із суїцидентами серед засуджених у виправних колоніях.

\section{Список використаних джерел:}

1. Про Національну стратегію у сфері прав людини : Указ Президента України від 24 березня 2021 року № 119/2021. URL: https://zakon.rada. gov.ua/laws/show/501/2015\#Text (дата звернення: 01.04.2021)

2. Поліщук Г.С., Тернавська А.А. Запобігання суӥциду серед засуджених у виправних колоніях України : монографія. Київ : ФОП Маслаков, 2020. 172 с

3. Голіна В.В. Об'єкт запобігання злочинності й об'єкт запобіжного впливу: поняття, співвідношення й значення для практики запобігання та протидії злочинності. Кримінально-правові та кримінологічні засоби протидіїзлочинам протигромадської безпеки та публічного порядку : збірник тез доп. Міжнар. наук.-практ. конф. до 25-річчя ХНУВС (18 квіт. 2019 р., м. Харків) / МВС

України ; Харк. нац. ун-т внутр. справ ; Кримінол. асоц. України. Харків, 2019. С. 64-66.

4. Голіна В.В. Об'єкт запобігання злочинності як фундаментальна кримінологічна проблема. Проблеми законності. 2017. Вип. 138. С. 150-160.

5. Поліщук Г.С. Щодо превентивного потенціалу режимних заходів запобігання суїциду серед засуджених у виправних колоніях. Удосконалення механізму правового регулювання суспільних відносин з урахуванням зарубіжного досвіду : збірник матеріалів Міжнародної науково-практичної конференції (м. Київ, 1 червня 2020 р.) / відп. ред. О.Ю. Бусол. Київ : Ліра-К, 2020. 218 с.

6. Про Уповноваженого Верхової Ради України з прав людини : Закон України від 23 груд. 1997 р. № 776/97-ВР / Верховна Рада України. URL: https://zakon.rada.gov.ua/laws/ show/776/97-\%D0\%B2\%D1\%80 (дата звернення: 01.04.2021)

7. Поліщук Г.С. Щодо антисуїцидальної специфікації роботи відділень соціально-психологічної служби. Кримінологічна теорія і практика досвід, проблеми свогодення та шляхи їх вирішення : матеріали Міжвузів. наук.-практ. круглого столу (Київ, 28 трав. 2020 р.) : у 2 ч. / редкол. : В.В. Чернєй, С.Д. Гусарєв, С.С. Чернявський та ін. Київ : Нац. акад. внутр. справ, 2020. Ч. 1. 270 c. C. $203-206$

8. Положення про відділення соціально-психологічної служби : Наказ Міністерства юстиції України від 4 листопада 2013 року № 2300/5. URL: https://minjust.gov.ua/m/str_45353 (дата звернення: 01.04.2021)

Stanislav Mozol, Hennadii Polishchuk, Anastasiia Ternavska. Organizational-legal means of preventing suicide among convicted persons in Ukrainian penitentiaries

The relevance of the article is that an important indicator of the level of protection of life and health in penitentiary institutions is the number of cases of unnatural death, including suicide. The study of this phenomenon is an important task, the propersolution of which can significantly improve the process of execution and serving of criminal sentences and positively affect the possibility of reintegration of released persons into society. After all, the existence of such forms of behavior indicates, on the one hand, the inability of the state to ensure the security of the person, and on the other hand, the inadequate choice of punishment for a person who is a potential carrier of suicidal tendencies. The spread of this negative phenomenon is growing and becoming a serious social problem, and the sharp rise in suicides has a negative impact on the stable functioning of penitentiaries and makes it impossible to ensure the safety of special forces, which is one of the main responsibilities of penitentiary staff. The purpose of the article is to characterize the main directions of suicide prevention among convicts in correctional colonies of Ukraine, in particular its organizational and legal component, and to formulate proposals for its improvement. The article highlights, describes and explains the organizational and legal measures to prevent suicide among convicts in correctional colonies of Ukraine. Proposals for the anti-suicide specification of the national preventive mechanism have been developed. The necessity to remove from the text of the law the provisions of Part 4 of Art.19-1 of the Law of Ukraine "On the Commissioner of the Verkhowna Rada of Ukraine for Human Rights" on the work of monitors solely on the basis of a separate order of the Ombudsman. The necessity of creation of separate sectors of suicide prevention in the structure of departments of social and psychological service of correctional colonies is proved. Changes and corresponding additions to the Regulations on the department of social and psychological services are designed. It is proposed to amend the List of websites to which convicts are allowed to access, and to develop a draft program of differentiated educational impact on convicts "Overcoming self-destructive conditions", the introduction of which should eliminate the organizational and legal gap in dealing with suicides among convicts in correctional colonies.

Key words: suicide, correctional colonies, convicts, preventive activities, organizational and legal measures. 